ppi $201502 Z U 4645$

Esta publicación científica en formato digital es continuidad de la revista impresa ISSN-Versión Impresa 0798-1406 / ISSN-Versión on line 2542-3185Depósito legal pp $197402 Z$ U34

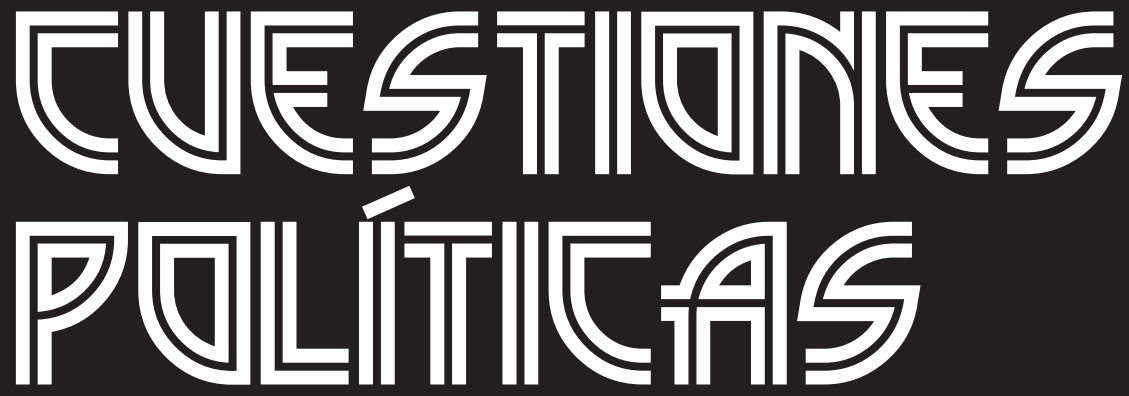

Instituto de Estudios Políticos y Derecho Público "Dr. Humberto J. La Roche" de la Facultad de Ciencias Jurídicas y Políticas de la Universidad del Zulia Maracaibo, Venezuela
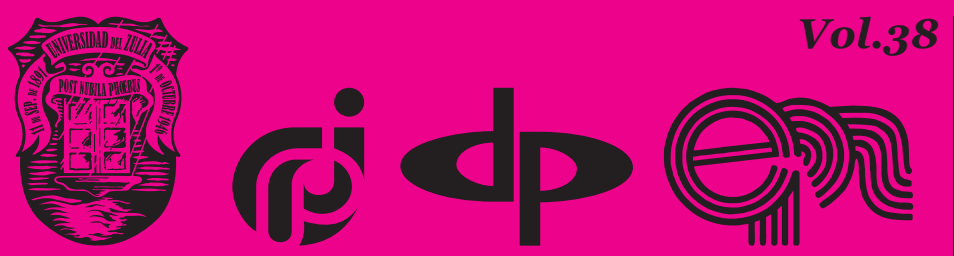

$N^{\circ}$ Especial 1era Parte 2020 


\title{
Formation of political journalism as an institution in Azerbaijan: areas of development and activity
}

\author{
DOI: https://doi.org/10.46398/cuestpol.38e.o9
}

\section{Bahruz Guliyev *}

\begin{abstract}
It analyses the methodological foundations and essence of political journalism as a social institution, as well as the interaction of politics and journalism. Based on an interdisciplinary study, the article gives an account of the peculiarities of the realization of political journalism in the world and in Azerbaijan, stating that political journalism performs informative, communicative, ideological, cultural, enlightening, organizational and recreational functions. It concludes by highlighting the power of the media to carry out democracy, in political decision-making and debates through the power of information. In other words, the power of the media is the power of political journalism, the unity of the media with political and economic power. It also points to the place and role of social media political science. Political media science is considered a new phenomenon in former Soviet republics. It is characterized as a phenomenon that encompasses systematic political theory, the science of modern comparative media, media, and politics. It is also believed that the political science of the media is related to the mediation of politics and the political processes of 1 to
\end{abstract} information.

Keywords: independent political journalism; media power; democratic press; information security; state consciousness. 


\section{Formación del periodismo político como institución en Azerbaiyán: áreas de desarrollo y actividad}

\section{Resumen}

Se analiza los fundamentos metodológicos y la esencia del periodismo político como institución social, así como la interacción de la política y el periodismo. Con base en un estudio interdisciplinario, el artículo da cuenta de las peculiaridades de la realización del periodismo político en el mundo y en Azerbaiyán, afirmando que el periodismo político cumple funciones informativas, comunicativas, ideológicas, culturales, esclarecedoras, organizativas y recreativas. Se concluye destacando el poder de los medios en la realización de la democracia, en la toma de decisiones políticas y los debates a través del poder de la información. En otras palabras, el poder de los medios es el poder del periodismo político, la unidad de los medios con el poder político y económico. También señala el lugar y el papel de la ciencia política de los medios de comunicación social. La ciencia política de los medios se considera un fenómeno nuevo en las exrepúblicas soviéticas. Se caracteriza como un fenómeno que abarca la teoría política sistemática, la ciencia de los medios comparativos modernos, los medios y la política. También se cree que la ciencia política de los medios está relacionada con la mediación de la política y los procesos políticos de la información.

Palabras clave: periodismo político independiente; poder mediático; prensa democrática; seguridad de la información; conciencia estatal.

\section{Introduction}

Relevance of the paper. In the $2 \mathrm{O}^{\text {th }}-21^{\text {st }}$ centuries, influenced by the west, former Soviet republics entered a stage of modernization of their political system. This marked transformation and innovations in the entire political system, including political institutions, political values, political activity, and relations.

Modernization means quality changes in the political system. As a social institution, political journalism plays a key role in realizing these changes. Political journalism is a means of realization of the political strategy.

The role played by political journalism in the society`s political life as a social institution has the following theoretical models:

1. Pluralist model.

2. Ruling ideology model. 


\footnotetext{
Bahruz Guliyev

Formation of Political Journalism as Institution in Independent Azerbaijan, its Development and 136 Activity Areas
}

3. Elite value model.

4. Market model.

Political journalism shapes public opinion, educates masses politically, influences political processes, contributes to socio-political governance process, legislative and administrative state decision-making, legitimizes the political system, reflects, and protects society, group, individual, state, and national interests. Political journalism and journalists are responsible to society and instill political culture in society.

Political journalism has the following influence areas:

1. Ensuring the society`s information interests under conditions of globalizing information.

2. Ensuring publicity, democracy.

3. Organizing debates, discussions on main problems of public life.

4. Hailing and criticizing programs of state, party, public figures, and separate leaders.

5. Instilling moral values, political culture, patriotism, statehood values in citizens.

As a traditional and modern, internet and social network media, public judge, advocate of justice and truth, national interests, political journalism is becoming the "fourth power".

\section{Literature review}

In the western political science, modernization theory emerged in the U.S. in the mid-20th century. Society`s modernization was studied by D. Anter, S. Huntington, G. Almond, R. Dahl, D. Easton (Hasanov, 1999). There are liberal and conservative approaches to this issue. The first approach to the impact of the mass media on political processes was propaganda and journalistic approaches. Canadian philosopher and public intellectual Marshall McLuhan linked electronic media to information globalization (Marshall, 1995).

One of the prominent schools studying the role of political journalism in the political system as a social institution is the Frankfurt school.

Researchers determined several concepts in relation to this problem, including "Political journalism", "social institution", "information globalization", "political system", "modernization", "communication", "mass media", "media political science", "media power", "mediazation of 
politics", "traditional and innovative media", etc. Some researchers (B. Baghirov, B. Grushin, E. Dennis, D. Merill, V. Savin and others) approach to political journalism as a real political process. They studied the work, methods and forms of the mass media in the political process (Mahmudov, 1999).

Other researchers (B. Dubin, S. Kara-Murza, O. Karpukhin and others) studied the socio-psychological impact of political journalism on the political activity, consciousness of participants of the political processes. G. Hajiyev, I. Panarin, O. Koltsov, Y. Machkov and others studied the role of political journalism in the political processes and its relation to modernization process (Hasanov, 1999).

Some Azerbaijani researchers studied different aspects of political journalism. R. Mehdiyev, A. Hasanov, G. Maharramli, S. Khalilov, A. Ashirli, K. Niftaliyev studied journalist ethics, freedom of press, history of press, political journalism concepts and typology, international journalism; A. Aslanov and Z. Babayev studied modern media, ICT and media problem; A. Rustamova and F. Babayev studied modernization and political journalism, and the role of the media in civil society (Hasanov, 1999; Khalilov, 2001; Mahmudov, 1999).

However, the process of formation of political journalism as an institution in Azerbaijan in the years of independence was not systematically and comprehensively studied from the perspective of political science at the doctor of science level. Objective of the paper is to study the role and place of political journalism as an institution in Azerbaijan `s political life.

Order to achieve this objective, the following tasks were set:

* To study the situation and development tendencies of the modern political journalism in Azerbaijan.

* To examine interaction between major subjects of information politics.

* To discover the peculiarities of the use of methods and ways of reflection of political processes in political journalism.

Methodological and theoretical base of the paper lies in historical, philosophical, sociological, and political works of the world public intellectuals who studied different aspects of political journalism. The study features a number of methodological academic principles: determinism, relevance, unity of form and content, academic professionalism - principles of political science, sociology and journalism - historical, institutional and structural function methods. A sociological survey and statistical approach were also applied. 


\footnotetext{
Bahruz Guliyev

Formation of Political Journalism as Institution in Independent Azerbaijan, its Development and 138

Activity Areas
}

Empirical base of the paper lies in the following documents and materials:

- international documents on the formation of global information society.

- national conceptions for development of the national media.

- laws and normative acts of the Republic of Azerbaijan.

- codes of professional ethics for journalists in Azerbaijan and foreign countries.

- periodical press materials.

Scientific novelty of the paper lies in the following:

1. determination of the role and place of political journalism as a factor of the formation of political journalism in modern Azerbaijan based on a comprehensive study.

2. objective substantiation of the increasing role of political journalism in the process of Azerbaijan`s transformation.

3. study of the realization of political journalism, information politics and civil position against a background of the formation of global information society and expansion of the political aspects of journalism.

4. study of the practical activity - based on empirical material - in the formation of political journalism.

5. determination of main aspects of the formation of political journalism and the activity of journalism towards building a humane society and ensuring sustainable development.

Theoretical and practical significance of the paper lies in the fact that its materials can be used for improving the political journalism theory and in practical activity of journalists.

\section{Political journalism as area of socio-political activity and civil institution}

Studying Azerbaijani political journalism aims to highlight the place and role of journalism in political processes taking place in the country, and forms and methods of coverage of the political life by the media.

The primary goal is to study the state of the modern Azerbaijani political journalism and its development tendencies. 
Examine interaction between major subjects of politics in the country`s information arena. Discover peculiarities of the use of methods of objective, unbiased coverage in political journalism of political processes taking place in the country.

As a political institution, journalism represents vital importance to society, becoming the decisive factor of political struggle, and economic, socio-political, and cultural event. Western researcher Paul Virilio writes that under such circumstance's journalism acts as 1. a social institution; 2. a system of special theoretical and applied knowledge; 3 . an institution of mass media methods and means. As suggested by Virilio, journalism is a unique form of a socio-political institution (Sheygal, 2004).

Nowadays political journalism also manifests itself as an indicator of the balance of political systems. Mediazation of politics and the strengthening of political journalism and the mass media increases demand for information of the work of authorities. Y. I. Sheygal believes that "politics is the only profession which has a mass-oriented communication, and which is, in fact, the primary element conditioning the existence of political communication (Sheygal, 2004). The author points out the increasing role of politics in society`s life.

Political journalism reflects the processes taking place in the country`s political life. O. V. Sulina from Saint Petersburg University says that "although political journalism plays a key role in interpreting, explaining and informing about political decisions, it can also affect the making and change of political decisions" (Sulina, 2015). She believes that under conditions when there is no alternative position, political journalism tends to defend authorities ' views and cause imbalance of political forces and political system.

Political journalism reflects the views of the government, legislative and executive authorities, social groups, and parties. Informative political journalism and propaganda political journalism usually differ. Propaganda political journalism is considered as a characteristic of totalitarian society. "In good-structured, multi-party societies, political journalism reflects the necessary element of the socio-political life." In totalitarian regimes and single-party systems, journalism loses its informative function, and only propagates and encourages party program.

Trendy developed democratic societies, political journalism is an independent media outlet separate from the state and its government branches, parties, and public organizations. Unity of people's national and universal values, wide reader audience make up the social base of objective, independent, democratic political journalism. Western doctrines, concepts, theories and approaches analyze political processes and the impact of the mass media on people`s life. American researchers Shanto Iyengar and 
Formation of Political Journalism as Institution in Independent Azerbaijan, its Development and

Donald R. Kinder say that television newscasts shape judgement of citizens with poor political wisdom and experience. Those who rarely encounter with politics deem delivery of news through the network as irreplaceable. Political journalism reflects political diversity in society (Shanto and Kinder, 1987).

A group of Western conceptions put emphasis on managerial and manipulator function of the press. Most prominent representatives of this thought are Walter Lippmann, Herbert Schiller, T. Sorensen, G. Glasberg and others. Another group of researchers, including E. Mayo and others single out communicative function of the press. According to them, the primary task of the mass media is to implement horizontal and vertical relationships (Sulina, 2015).

Like all types of media, political journalism fulfils informative, enlightening functions, carries out control and observes activity of state, forms a political area. Researchers point our three peculiarities of communication sources of the media - truthfulness, attractiveness, and power. Other peculiarities include dynamism, communication, authoritarianism, study of journalistic aspects of the activity of political journalism. "Language and style of articles affects effectivity of sources". The author rightly underlines that contradictions between the social structure and development not only limits the media 's influence capabilities, but also necessitates its becoming a censorship and totalitarian control tool.

Harold Innis, a representative of technological determinism, believes that "monopolies of knowledge encourage centralization of power". Innis describes information as a political force. Another representative of this theory, Marshall McLuhan, believes that changing communication stages encourage the homogenizing process in society (Marshall, 1995). The triple-M theory, which is wide-spread in the west, includes the concepts of mass society, mass media and mass culture, while political economy theory is a leftist socialist and neo-Marxist theory, which claims that the mass media (including political journalism - B. G.) weaken conflict of interests and address class disagreements.

Many western conceptions draw attention to the issues that are the subject of political journalism - change in people`s political views and political socialization process. They note that this process takes place in two forms - direct and indirect. Direct form includes political experience, political organization and similarity, which emerge under influence of political journalism. Indirect forms of political socialization include interpersonal communication, participation in different non-political organizations and movements, the spread of values and norms applied in other spheres of social life to political objects and relationships process. Information power occupies a central place in the real context of the understanding of political journalism as the fourth power. Political journalism acts as a power bearer. Power of journalism is realized through masses. 
The studies in this area allow to make the following conclusions: firstly, in the 21st century, world political journalism will develop strictly within the framework of political paradigms; secondly, Azerbaijani political, analytical journalism paves the way for the establishment of the country`s information arena only within the framework of analytical discourse; thirdly, political journalism should be made a priority in the process of preparation of specialists in journalism at Azerbaijani higher education institutions. Political journalism should shape the person`s political culture, his statehood and patriotic consciousness; fourthly, Azerbaijan should build its information market and information arena. The creative aspect should play a central role here along with the economic aspect.

Political journalism is a means that influences citizen, society, state and power. Political journalism, which is capable of exerting mass and political influence, affects not only the way citizens understand separate political events, but also affects their political views. Obviously, population `s political activity directly depends on the position of political journalism because it affects the way society`s political consciousness and value orientation change, social changes encourage mass political processes.

Political journalism occupies a special place in society and functions on a democratic basis. On the one hand, it plays a role in management relations in society, and between three manifestations of power (subject of governance) and people (object of governance). It provides information of, distributes and explains the government `s decisions, and broadcasts masses `reaction to these decisions and people `s demands from the government. So political journalism acts as a means of governance. Being one of the branches of the media, which cover political events, political journalism is the subject of study of political science. Political journalism provides a limited study of the activity of the authorities and socio-political processes from internal policy to international life and all aspects of social life.

Quality analytical journalism lies at the heart of political journalism. "Analytical journalism is efficient applied political science and sociology. More precisely, knowledge of laws of political and social development makes the core of this journalism.". In the west, politics is more open. In the former Soviet republics, journalist investigation is one of the weakest sides of journalism. Close connection between the authorities and the business is one of the main reasons behind this.

Socio-political life and realpolitik pursued by the authorities and the opposition is the subject of political journalism. The main task is to explain the developments to society, and to cover - to the maximum extent realpolitik taking into account the country`s national strategic interests. It is not journalists, but the ruling elite, editors-in-chief of leading media, publishers, influential journalists and local population who make the modern political agenda. Professional journalists write about real and 
Formation of Political Journalism as Institution in Independent Azerbaijan, its Development and

important, true political processes. On many occasions, journalists express their views covertly.

Although journalist investigations are widespread in the west, searches for the genre are still ongoing in the former Soviet republics.

The Scientific literature, investigative journalism is sometimes characterized as "black PR". Journalism investigation reflects modern realities of intensive establishment of market relationships, severe political, economic and moral tumults relating to radical democratization of all areas of public life. These investigations aim to address problems such as crime, corruption, drug addiction, environment. Analytical view, openness of journalist position are main features of these investigations. But in some countries, under conditions of development of civilized forms of democracy, improvement of society`s moral and economic situation, stabilization and peaceful development, journalist investigations take a completely different turn, and investigation almost disappears with the emergence of political killings and "dirty technologies" of PR.

In terms of the content and literary processing, journalist investigation features two important points. Firstly, journalist shows not only results of his study, but also reveals all mechanisms and methods used, turns the readers into interested participants of the study. The reporter expresses his own attitude to the conflict using applied means of expression, making an emotional impact on the readers, listeners, spectators... Secondly, the author tries to increase tension given the composition of journalistic study. By grouping and giving description of facts, the author consecutively reveals new aspects of the theme, relates them in accordance with a single story line, increasing reader `s interest in finding a solution to the issue. So journalist investigation has some features of the detective genre. Obviously, apart from assuring the reader in authenticity of the material, truthfulness of his own judgement, journalist also manages to attract public attention to his study to ensure objective assessment of his material.

A journalist study features an analysis of documented facts of the reality in the system of analytical genres, an immediate analysis of topical problems. So a political journalism study is distinguished by inclination to genres with detective elements.

Unity of politics and journalism occupies a central place in the activity of political journalism. This process is very active in dynamic development of information and communication technologies in the modern world of politics. Interaction of journalism and politics necessitates specification of some concepts. This can especially be related to "political journalism" term. In many cases, political journalism is understood as a political publication, independent press outlet or the one run by the business or state. Irrespective of its owner, political journalism is characterized by political comments and 
information. This type of journalism is distinguished by political discussions and communication at different levels.

Political journalism fulfills the following functions: "1. Informative function, which includes collection, processing and distribution of information on all important elements of the political system. 2. Analytical function, which puts forwards information featuring knowledge about politics and political process. 3. Political socialization function, which features mastering political norms, values and conduct standards together with the normal activity of political systems. 4. Criticism and control function, which puts forward formation of attitudes and comments on the processes taking place in the field of politics" The author shows that the growth in the political importance of political journalism leads to increase in its role in political socialization and political mobilization, criticism and control of political processes.

Modern communication technologies are strengthening relations between politics and journalism. Technological progress and information revolution made a breakthrough in the development of political communication. New communication areas, social networks have peculiarities of political communication.

The subject of study of political journalism is of great interest from the point of view of different sciences. Peculiarities and problems of political journalism are studied by political science, sociology and theoretical journalism. The subjects of its analysis feature different manifestations. "The first subject of study is the content of political journalism. The analysis of the content includes the study of the theme of articles, and periodically remarks of journalists, political journalism dimensions. Spatial dimensions put forward level of political life of district, municipal, federal, intergovernmental, global relations. Temporal dimensions of the content of political journalism include the study of the history, current political conditions and political forecast. The second direction is an institutional study. In this context, journalism is studied as a political institute, element of the political system.

In institutional approach, the subject of study lies in level of activity of political journalism (local, regional, federal, international), interaction between journalists and media with political forces and institutions, typology of political journalism (parliament, party, official, opposition journalism, etc.). Thirdly, the subject of the study lies in the functions of political journalism. The functional analysis features the study of the independence of journalists and political tendencies, political effectiveness of political journalism, its qualitative and quantitative dimensions. The fourth area of the analysis lies in the study of political activity of political reporters, creative laboratories of opinion journalists and political scientists, their work with information sources, peculiarities of text writing, ethic 


\section{Bahruz Guliyev \\ Formation of Political Journalism as Institution in Independent Azerbaijan, its Development and 144 Activity Areas}

fundamentals of activity". The subject of the study of political journalism is thoroughly analyzed from the points of view of content, institutional, functional perspectives and from the point of view of activity, its influence on public opinion, reflection and coordination of different political interests is highlighted.

Political journalism influences formation of political culture and ideology. It conducts comparative analysis of different political systems in concrete historical conditions, studies the political elite and groups, which are involved in political decision-making, reveals the truth through conspiracy theories and methods. Russian researcher A. Dugin believes that:

A conspiracy method is widely applied in political science and political journalism: first and foremost, the commentator and observer never knows the essence or hidden causes behind he developments and therefore uses uncertain means or shows voluntarist facts - and "conspiracy theory" comes to help here (Dugin, 2005: 49).

The author points out that conspiracy method is based on covert interaction of political figures and coordination of events and claims that this method is supposedly used in some cases. Study goals of political journalism can be empirical and applied. It uses systematic study and structural and functional methods. Political journalism studies focus on theoretical methods, scientific analysis, induction, deduction, study of institutions and organizations. Institution reflects the form and essence of political functions and relations. For Hegel, institution "is a sum of roles and statuses in the system of public relations determined to ensure certain social demands" (Hegel, 1974). The author considers institution as a stable form of socio-political experience, which emerges with the help of sociopolitical norms, which lies at the heart of socio-political life, and which ensures firmness of socio-political relations (Novruzova, 2011).

In socio-political life of democratic societies, government institutions, civil society and journalism maintain equal cooperation. Political journalism is closely involved in government-society dialogue in open societies. In democratic societies, political journalism has an institutional status and grows into a media organization after obtaining the status of institution through fulfilling a regulatory function and executing self-governance and control (Hegel, 1974).

In socio-political systems, apart from a regulatory function, political journalism also fulfills the integrative (relating to responsibility of the journalist to ensure political interests of society) and relational functions in accordance with cultural values, and political and ideological rules. Political journalism, which plays a key role in shaping public opinion, is based on the principles of isolation, specification and restoration, which are part of the socio-political control method. 
Political journalism is also based on dialectical and comparative methods. It also uses regional-geographical, temporal-historical comparisoncomparative historical method. Comparative study features comparative method, which reveals common, universal and distinctive peculiarities of political events based on comparison. Comparative approach uses two means: the understanding based on hermeneutical method and comparison based on this knowledge.

\section{Formation and development peculiarities of political journalism in Azerbaijan}

Political journalism, which reflects the political life, was established in Azerbaijan in the late 19th-early 20th century. Political journalism in our country has witnessed several historical development stages:

1. Political press, which operated under Tsarist censorship when Azerbaijan was part of the Russian empire in the 19th century.

2. political press of Azerbaijan Democratic Republic.

3. Development peculiarities of Soviet political journalism.

4. Political journalism in independent Republic of Azerbaijan.

Although Northern Azerbaijan lost its political independence within the Russian Empire, it was thanks to Russia that it modernized, embraced many Western liberal values, Europeanized, and built its institutions based on national identity, theatre, and political press.

In 1975, Hasan bay Zardabi founded "Akinchi” newspaper, the first press outlet in Northern Azerbaijan, which was part of the Russian empire. "Akinchi" newspaper played a crucial role in the establishment of Azerbaijan`s political information policy. Declared by "Akinchi" newspaper, the principles of the national democratic press - enlightenment, modernization, purity of ideology, promotion of national objectives, unity of universal values and national traditions, adjustment of literary language to colloquial speech, objective coverage of events laid the foundation of future development of Azerbaijan `s national and democratic press. This newspaper has been influencing the traditions of political and democratic press in Azerbaijan in the mid-20 ${ }^{\text {th }}$ century until the establishment of Azerbaijan Democratic Republic (Akinchi, 1876).

The enlightenment idea coincided with the emergence of political and democratic press at that time. The press rose up against colonialism, internal feudal rules, ignorance, and started to raise the society`s awareness through enlightening and political information. The founding 


\section{Bahruz Guliyev \\ Formation of Political Journalism as Institution in Independent Azerbaijan, its Development and 146 Activity Areas}

of "Akinchi" marked the era of domination of the national, politicallymotivated information in Azerbaijan. This newspaper contributed crucially to learning, developing mother tongue, mastering world information in national language. "Akinchi" newspaper was providing the society with news articles on science, enlightenment, culture, literature and arts, public, political, academic and military elite of the country, and producing information educating all layers of the society, including children, youth, women, men, and covering the masses.

"Akinchi" newspaper went down in the history of Azerbaijan `s press as the first newspaper with the national status. For its typological nature "Akinchi" was characterized as "the newspaper, which received the national newspaper status". "Akinchi" newspaper laid the foundation of the spread of free, open, true, reliable information and this tradition was then continued by other press outlets. Hasan bay Zardabi wrote about the political essence of the newspaper: "A newspaper cannot tell fairytales as a darvish. It should show to people negative and positive sides of works as a mirror so that people know and address their problems. "Akinchi" newspaper set itself a goal of correctly covering the political reality and raising people`s awareness of political realities. Hasan bay Zardabi was sharply criticizing the arbitration right and rules, dirty political trick of the existing system. "Akinchi” grew into a press outlet, which influenced people`s public and political consciousness and laid the foundation of political and democratic journalism.

The political and democratic traditions of "Akinchi" influenced the emergence of a new generation of intelligentsia who were promoting the ideas of political independence. A new type of democratic political press emerged in Azerbaijan, which was closely related with our people`s struggle for political freedom and social justice. "Established and developed by Azerbaijan`s outstanding thinkers, enlighteners and public figures, progressing democratic traditions and ideas, contributed to the emergence of a new, more perfect stage of the democratic press." (Giffin, 1967).

"Sharg-Rus" newspaper (established in 1903), "Hayat" (established in 1905) "Fuyuzat" (established in 1905) magazines put promotion of progressing, enlightening, unity, freedom ideas at the center of their activity. Those times A. Huseynzade was promoting the principles of Turkization (national self-consciousness), Islamization, Europezation, language and religion, national and universal freedom (Huseynzade, 2005). "Molla Nasraddin" magazine, a new type of publication promoting democratic information, played an invaluable role in shaping Azerbaijan `s information policy in the mid-20th century. The magazine set itself the following priorities: 1. Struggling for simplicity and purity of Azerbaijani language, which lay at the heart of Azerbaijanism; 2. Using artistic laughter, criticism, and destructive ridicule against socio-political menace; 3. Promoting 
western liberal and democratic and eastern cultures, as well as national and moral values (Huseynzade, 2005).

The magazine was sharply criticizing colonialism, political ignorance, external and internal enemies, and urging the people to wake up from ignorance. The magazine was providing an insight into both national and universal problems, and highlighting the necessity of applying traditions of socio-political, economic, and moral life as well as national and cultural peculiarities of the near and far foreign countries in Azerbaijan.

Researchers believed that there were a number of reasons behind the magazine`s success and its eminence outside Azerbaijan in the entire Caucasus, Russia, Asia and the East, including its truthfulness, courage to tell the whole truth, commitment to moral and professional values, modernity and relevance, possession of serious criticism targets, shortness and seriousness of its content, unity of the national eastern flavour, its highly-qualified staff which included the most progressive, patriotic and creative intelligentsia of that time, attractiveness of its material both from the points of view of content and literary and graphical composition and originality, the study and promotion of culture, literature, arts, classical poets and writers of the west and east, Azerbaijan, Russia, and the rest of the world.

Addition to struggling for national values, "Molla Nasraddin" magazine was also promoting the necessity of improving the socio-political consciousness of readers and the scale of information spread to European standards. The early 20th century, several pro-Marxist party newspapers emerged (Zasurskiy,1999). In 1904, the first Azerbaijani language underground political social-democrat newspaper stared to operate in Baku. "Hummat" newspaper was criticizing the political backwardness, public violence, exploitation, religion, and advocating women `s rights and freedoms. In the years 1900-1920, Marxist researchers classified political journalism into five categories for the socio-political content of information and idea priorities:

* Bolshevik press.

* Revolutionary democratic press.

* Democratic bourgeois press.

* Liberal bourgeois, or religious nationalistic bourgeois press.

* Feudal clerical press.

* Marxist and pro-Marxist press.

* Democratic, enlightening press.

* Pro-religious press. 
$\begin{array}{ll} & \text { Bahruz Guliyev } \\ & \text { Formation of Political Journalism as Institution in Independent Azerbaijan, its Development and } \\ 148 & \text { Activity Areas }\end{array}$

Its activity, Marxist, and pro-Marxist press:

* insisted that all countries are experiencing an antagonistic, fierce struggle between two classes - the rich and the poor.

* put emphasis on the protection of the rights and interests of the poor.

* gave preference to a state building that prioritized equality of national rights, friendship of nations and internationalism.

In 1918, at the time of Azerbaijan Democratic Republic, the national and democratic state information policy was for the first time introduced.

"Press Charter" adopted by the parliament of Azerbaijan Democratic Republic gave impetus to the development of the state information system. This charter abolished censorship and laid the legal framework for the establishment of a free, democratic political journalism in Azerbaijan.

It marked the creation of a crucial and firm legal framework for establishing a democratic, state, political press body. By adopting this charter, Azerbaijan ensured the legal basis for the founding of the media. The tenure of Azerbaijan Democratic Republic saw the publication of newspapers and magazines for all layers, classes and parties in the country. "Azerbaycan", which was a political, public, literary and economic body, an independent newspaper, started to provide people with objective information those years. The newspaper was featuring articles on political, economic, social, scientific, literary, educational topics, promoting the ideas of Turkization, Islamization, modernization, and publishing official documents, government resolutions and decrees.

Azerbaijan `s political information bodies at the time of ADR included "Azerbaycan", "Istiglal”, "Basirat”, "Achig soz" newspapers, "Ganjlar yurdu", "Sheypur" democratic and youth bodies, "Madaniyyat", "Afkarimuallim" newspaper covering cultural news, and "Maktab", "Dabistan" newspapers highlighting school life.

The Azerbaijani newspapers and magazines were widely covering the issues of independence, economy, culture, arts, education and politics. Azerbaijan Democratic Republic's tenure featured the attempts to establish democratic political journalism. So it was at the time of ADR when independent, democratic political journalism was founded.

The collapse of ADR and Sovetization of Azerbaijan in 1920 saw the imposition of the Soviet censorship on the activity of the Azerbaijani press. "On state monopoly in the media sector", "On revolutionary press tribunal" decrees were issued. The state censorship was then replaced with party censorship. The years of perestroika in the Soviet Union in the late 2oth century marked democratic changes in the activity of political journalism. In the years of Azerbaijan `s independence, political journalism in the country 
made great strides, censorship was abolished. This paved the way for access to free information, establishment of democratic information environment and free media. Academician R. Mehdiyev writes in this connection:

\begin{abstract}
The Azerbaijani state, which chose a democratic development path, has taken and continues to take notable steps towards establishment of a free, independent media, which is one of the permanent attributes of democracy. The provision of the freedom of speech, expression, press, free publication of a number of newspapers and magazines is indicative of the creation of all the conditions necessary for the full establishment of democracy and free execution of the freedom of press in the country (1999: 65).
\end{abstract}

The freedom of press, freedom of speech has become the Azerbaijani people`s political and democratic lifestyle, the publication of the press has been facilitated, favorable conditions were created for the activity of independent television channels along with the state television in Azerbaijan (Mehdiyev,1999).

A number of different entities of political journalism emerged in the country on the eve of independence - Soviet press outlets, journalism, which was hesitating between tradition and modernity and democratic political journalism.

Apart from being colorful and controversial, this political journalism also aroused greet interest. For its political goals, approach to problems as well as its content, political journalism of those years can be classified as follows:

“- party, soviet press, which preferred old methods and did not want to get rid of the Soviet and party fetters.

- newspapers and magazines that were hesitating between old work methods and new requirements.

- press outlets, which gave preference to the freedom of speech, freedom of press, democratic values, censorship-free publishing, and struggled for Azerbaijan `s independence and freedom”. The author points out that political journalism serves national interests.

The national statehood line has been maintained and is being successfully developed in Azerbaijan, the country is considerably strengthening and improving the legal framework on the mass media. Azerbaijan has made great strides in developing the freedom of speech, freedom of thought, freedom of press. The Public television channel was opened, and the country embarked on a landmark new stage in ensuring the independence of political journalism, building a democratic information environment, in other words, in developing the state information policy, information communication technologies. The information society has reached its peak of development in the country, advanced information resources 


\section{Bahruz Guliyev \\ Formation of Political Journalism as Institution in Independent Azerbaijan, its Development and 150 Activity Areas}

were established, information flow and use systems, information and communications infrastructure were improved to the world standards, free circulation, search and access to information was ensured, constitutional rights in the field of information politics were successfully executed.

\section{Conclusion}

Being one of the integral elements of political system, political journalism influences mass political consciousness and practice as well as statehood consciousness through public opinion mechanism, rather than directly. Statehood consciousness of the independence period is completely different from the state-party consciousness of the Soviet times. If the Soviet time state-party consciousness bearers were the ruling elite and ideologists, it is the entire nation, country citizens who are bearers of the statehood consciousness in the independence period. Statehood is, if one can say so, the essence of the national self-affirmation process in the political dimension. This means that the nation`s, people`s capability to govern, to assume power is linked to statehood. One point should be emphasized. Statehood can exist without a state. That is, if the nation, which once lost its state, has statehood consciousness means that this nation has its statehood.

What should be taken into account is that if the nation, which has no state, but has only statehood, protects its position, it is a guarantee that this nation will build its own state sooner or later. Azerbaijanis can be cited as an example of this. Take a look at history: despite being victims of oppression and despite the fall of our state several times, we have managed to build our own state again. Obviously, even at the times when there were no national states, peoples preserved their statehood consciousness traditions and feelings.

The state-party consciousness was built up by political views, visions featured in political documents - programs, conceptions and doctrines. The state-party consciousness fulfilled the function of mobilizing masses to achieve collective goals, rather than assuring people. Formed influenced by political journalism, statehood consciousness allowed "to think independently of life and world and act in accordance with this".

Statehood consciousness embraces national peculiarities, national ideals and ideas, public moral values, patriotic values and patriotism itself.

Political journalism should not split the nation with its destructive activity but should unite it around national ideas by promoting statehood consciousness. Azerbaijan`s national interests demand the dialogue among the country`s key political forces, and unity for the sake of national statehood. National political journalism should understand that statehood 
consciousness is a high, national value and force, which embraces people `s moral values and rule of law. By reflecting the interests of people and state, political journalism should serve Azerbaijani statehood and become an advocate of statehood consciousness.

Since statehood consciousness is a value that is above all limited interests and preferences, political journalism, which serves the nation, people, our statehood, should set itself a primary goal of instilling statehood goals in every citizen. A multi-profile, responsible political journalism should be an objective, fair chronicler of its time...and be preoccupied by the problems of motherland and people, rather than political ambitions. They should first and foremost think of state building, the strengthening of statehood...”. The main criteria of the activity of political journalism should be committed to national interests and promotion of statehood. Statehood consciousness should capture the hearts and minds of people as a sense of belonging to a state. The media are playing an active role in shaping and developing people`s statehood consciousness, instilling love for the motherland in them.

Statehood consciousness and traditions promoted by political journalism are one of the crucial factors in population`s becoming a nation, society members` becoming citizens, shaping people`s patriotic feelings, making love for motherland an integral part of the national identity. If everybody in the country pursue their own interests and ambitions and are indifferent to national interests, tradition of statehood will never emerge in this country.

Statehood is linked to a sense of national interests and "requires the ability to put love for motherland above all other values by going beyond personal, family, tribal, zonal, regional scale, respect and love one `s state symbols, be proud of achievements of one `s state, take the failures of one `s state as personal tragedy".

Political journalism explains the essence of "nationality" and "statehood" notions, highlights its meaning and different aspects, and promotes the values of state building and statehood.

Reinforcing statehood in public consciousness, restoring statehood traditions is among primary goals of political journalism. "If there is statehood, those who love their people and want to serve them, try to contribute to the country`s progress in their own areas of profession and to express their opinion on processes taking place in society". Political journalism promotes Azerbaijanis, which embraces statehood consciousness and traditions.

Azerbaijanis is a phenomenon, which includes patriotism, national and moral values, national solidarity, statehood, nationality, universal values, unity of heredity and modernity. In political journalism, patriotic traditions, patriotic upbringing, moral, ethic qualities, unity of national and universal 
values, respect for mother tongue, national unity idea, democratic values, statehood traditions, sense of statehood, unity of universal and national traditions are included in Azerbaijanis and promoted.

Statehood traditions in the East, including in Azerbaijan, date back to ancient times, and are maintained today with certain breaks. "The existence of statehood traditions is related to uninterrupted history and experience of currently existing states" (Merril, 1974: 58). Whereas statehood was prospering in Azerbaijan, Europe was dominated by feudal disunity. Having been established at the modern stage, European statehood has now reached the peak of its development. Statehood traditions in Azerbaijan had been broken for long, which considerably weakened statehood consciousness.

Political journalism should study statehood traditions, statehood thought and interaction of self-consciousness and ethnic and national feelings. In Iran, which has ancient statehood traditions, statehood consciousness is strong. In this country, "Iranian" national identity and statehood consciousness stands above the national and ethnic identity. In Azerbaijan, splits, occupation that took place in the 19th century dealt a serious blow to statehood consciousness and thought. Although Azerbaijanis preserved their ethic and national feelings as part of the Russian empire and Iran, they were deprived of statehood feelings:

Although ethnic and national feelings were preserved to a pretty good level when Azerbaijan was part of Russia, statehood feelings and thought were considerably weakened. The beginning of the 2oth century saw the emergence of bourgeois socio-political relations, which was accompanied by important steps towards national self-consciousness. But statehood consciousness failed to be established because the state was short-lived." The author points out that restoration of independence in the late 20th century again stimulated the development of ethnic and national consciousness (Mammadov, 2009: 112).

Under the conditions of weakening statehood traditions, civil and statehood feelings, at a time when statehood consciousness was being very slowly restored, national and ethnic feelings began to rapidly develop. As we know from media reports this process led to tension with ethnic groups living in Azerbaijan in the first years of independence.

However, successful steps were made thanks to the balance of statehood and national and ethnic consousness. Political journalism played a key role in this, even bigger than science. Political journalism was writing about goals of statehood consiousness, patriotism, Azerbaijanism. The notion of "Motherland" embraces "goals of motherland", "service to motherland", "patriotism", "love for motherland" notion. The land where every nation lives, its spirit is its cradle because the feeling of homeland, the spiritual and moral values of the nation are formed in this ethnic area. Motherland is not only landscape or land. It embodies national and ethnic, statehood, socioeconomic and cultural values, which have been established for centuries, historical and modern mental peculiarities. 
Statehood, motherland, unity of national and state interests occupies a central role in political journalism. Some political journalism bodies overstep boundaries of social responsibility, betrayed national and state interests, violate not only norms of professional ethics, but also state and legal norms, and even conduct an anti-Azerbaijani propaganda. In fact, all political media should protect statehood, serve national interests, and interests of the motherland and people. The author considers violation of internal, professional ethics norms as moral irresponsibility, describes serving to external enemies and undermining national and state interests as hostility.

Statehood ideology, which is featured in political journalism, raises people as citizens who respect and are committed to their state, and teaches them to put love for the motherland, interests of the state and people above all.

By increasing legal and political culture in society, statehood ideology ensures coordination of the people`s personal lives and interests with the interests of the nation, the people`s participation in public administration, realization of democratic governance and coordination of statehood consciousness with statehood practice.

Statehood ideology is also closely linked with economic thought and economic culture. The implementation of reforms by the state is also linked to public, personal interests and lifestyle.

As statehood ideology, Azerbaijanism unites all socio-cultural interests of people with the constitutional democratic state, which protects and defends the nation `s national and cultural identity. This ideology represents a strong phenomenon, which establishes a single society in Azerbaijan unity of all Azerbaijanis and nations living in the country.

National and cultural values emerging in public thought are protected, enriched and developed by statehood consciousness. National ideas can spread and capture the nation `s minds thanks to statehood consciousness, psychology and ideology. As a historical and modern concept, Azerbaijanism has acted as a socio-political and moral phenomenon at all stages of the society`s development.

Having been reflected in political journalism, Azerbaijanism has today captured the hearts and minds of every Azerbaijani in the form of respect for the elders, national and moral values, state symbols, love for state attributes in the state policy, literary activity of creative people, works of culture and arts, linguistics, all areas of social life. As manifestation of national and state interests and love and respect for the Azerbaijani state, people, leader, one`s family, land, motherland, territorial integrity, history and modern values, Azerbaijanism is realized as a goal that unites all Azerbaijanis. 


\footnotetext{
Bahruz Guliyev

Formation of Political Journalism as Institution in Independent Azerbaijan, its Development and 154 Activity Areas
}

Statehood consciousness, thought and traditions lie at the heart of the Azerbaijani people`s national and cultural values, and constitutes unity of people, society and state. Being an element of political, economic, social and moral demands, these interests and values include the following:

- protecting Azerbaijan `s state independence, ensuring its political, economic, information, state, national and global security, ensuring the country`s integration into the world `s information space.

- realizing Azerbaijanism idea with the aim of strengthening unity of the Azerbaijani people.

- ensuring civil society institutes, including the freedom of speech, thought and press.

- turning statehood consciousness and thought into the people`s national, cultural and political asset in democratic society.

- developing the values that ensure solidarity and unity of the Azerbaijanis of the world, cultural and historical legacy, their statehood consciousness and traditions, language, religious, national consciousness, national identity, patriotism and national pride.

These problems embrace the existence of state and statehood, its development prospects, national unity, the country`s international influence. These issues can be considered as the terms conditioning the future activity of political journalism. In this sense, realization of statehood consciousness and implementation of state policy in this area holds special interest for political journalism.

Political journalism `s supporting positive sides of the policy to protect and ensure national interests and criticizing its shortcomings can be regarded as factors conditioning further development and influence of media outlets. $(8,25)$. From this point of view coverage of the state policy on national interests should always be a priority for the media. Promoted by political journalism, Azerbaijanism and independent statehood ideology, patriotism feelings encourage great love and respect for the state, nation and motherland.

\section{Bibliographic References}

AKINCHI, 1876. Newspaper. Baku, Russian empire.

DUGIN, Aleksandr. 2005. Conspiracy theory. Doc. AST. Moscow, Russia. 
GIFFIN, Kim, 1967. "The Contribution of Studies of Source Credibility to a Theory of Interpersonal Trust in the Communication Process" In: Psychological Bulletin, pp .104-120.

HASANOV, Avaz. 1999. Freedom of press and journalist responsibility. Metbuat ve demokratiya. AUN. Baku, Azerbaijan.

HEGEL, George Friedrich. 1974. Encyclopedia of the Philosophical Sciences. V1. Nauka. Moscow, Russia.

HUSEYNZADE, Ali. 2005. Formation of democratic press in the Republic of Azerbaijan (1991-2005). S.e.n., a.d.a.f. dissert. Baku, Azerbaijan.

KHALILOV, Salahaddin. 2001. Leader. State Society. AUN. Baku, Azerbaijan.

MAHMUDOV, Rasim. 1999. Moral terror behind the curtain of free press. Metbuat ve demokratiya. Baku, Azerbaijan.

MAMMADOV, Teymur. 2009. Democracy is the political face of modern Azerbaijani state. Elm ve Tahsil. Baku, Azerbaijan.

MARSHALL, McLuhan, 1995. Understanding Media: The Extensions of Man. McGraw-Hill. New York, United States.

MEHDIYEV, Ramiz. 1999. Place and role of independent press in democratic Azerbaijan. Metbuat ve demokratiya. Baku, Azerbaijan.

Merril, John. 1974. The Imperative of Freedom. Hostings House. New York, United States.

NOVRUZOVA, Nana. 2011. New tendencies and searches in Azerbaijani press on the eve of independence// "Azerbaijani journalism in the era of globalization: a look at sources and prospects" marking the 10oth anniversary of Azerbaijan `s outstanding public figure, opinion journalist, honored journalist, professor Nasir Imanguliyev. Materials of Republican research conference. Sharg-Qarb. Baku, Azerbaijan.

SHANTO, Iyengar; KINDER, Donald. 1987. News That Matters: Television and American Opinion. University of Chicago Press. Chicago, United States.

SHEYGAL, Elena. 2004. Semiotics of political discourse. "Gnozis" Publishing. Moscow, Russia.

SULINA, Olga. 2015. "Political journalism as indicator of balance of political system" In: Philological sciences. Theory and practice issues, Vol. 50 No. 8, pp. 191-193.

ZASURSKIY, Igol. 1999. Mass media of second republic. MSU Publishing. Moscow, Russia. 


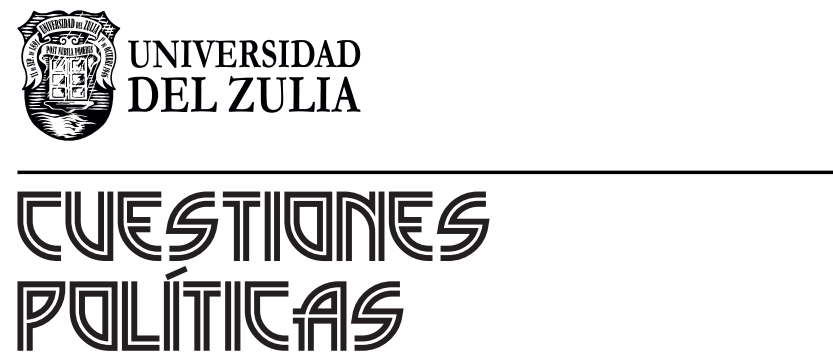

Vol.38 NEspecial

Esta revista fue editada en formato digital y publicada en octubre de 2020, por el Fondo Editorial Serbiluz, Universidad del Zulia. Maracaibo-Venezuela 